\title{
Kualitas Fisik Pakan Pellet Ayam Pedaging Fase Finisher dengan Penambahan Berbagai Bahan Perekat
}

\author{
Wahyu Jaelani Supriadi *, Jamila dan Jasmal A. Syamsu \\ Laboratorium Teknologi dan Industri Pakan, Fakultas Peternakan, Universitas Hasanuddin \\ Jl. Perintis Kemerdekaan KM. 10 Tamalanrea, Makassar \\ * Email: jaelaniwahyu24@gmail.com
}

\begin{abstract}
Abstrak
Penelitian ini bertujuan untuk mengetahui pengaruh penggunaan bahan perekat molases, tepung tapioka serta bentonit terhadap kerapatan tumpukan, pellet durability index dan kekerasan pakan pellet pakan ayam pedaging fase finisher. Penelitian disusun menggunakan rancangan acak lengkap terdiri dari 4 perlakuan dan 4 ulangan, dengan perlakuan adalah P0: ransum ayam pedaging fase finisher tanpa menggunakan bahan perekat, P1: ransum ayam pedaging fase finisher + molases $2 \%, \mathrm{P} 2$ : ransum ayam pedaging fase finisher + tepung tapioka 2\% P3: ransum ayam pedaging fase finisher + bentonit $2 \%$. Peubah yang diamati adalah kerapatan tumpukan, pellet durability index serta kekerasan pellet. Data yang diperoleh dianalisis menggunakan sidik ragam dilanjutkan dengan uji beda nyata terkecil. Berdasarkan hasil penelitian dapat disimpulkan bahwa tidak ada perbedaan kerapatan tumpukan pakan pellet ayam pedaging fase finisher dengan penambahan berbagai bahan perekat. Namun, terdapat perbedaaan kerapatan tumpukan dengan pellet tanpa penambahan bahan perekat. Tingginya kerapatan tumpukan pellet pada perlakuan tanpa bahan perekat diduga disebabkan oleh kecilnya ukuran partikel pellet dibandingkan pellet dengan penambahan bahan perekat. Efektivitas penggunaan perekat tepung tapioka dan bentonit menunjukkan pellet durability index yang lebih tinggi di banding penambahan bahan perekat molases. Sedangkan, nilai kekerasan pellet dengan penambahan bahan perekat bentonit lebih tinggi di banding bahan perekat tepung tapioka dan molases.
\end{abstract}

Kata Kunci : ayam pedaging fase finisher, pellet, perekat, sifat fisik

\section{Pendahuluan}

Pakan yang baik dari segi kualitas maupun kuantitas memegang peranan penting dalam menentukan produktivitas ternak dan efisiensi pemeliharaan ayam pedaging. Pakan berkualitas tidak hanya ditinjau dari segi nutrisi namun juga dari bentuk fisik. Bentuk fisik yang baik akan meningkatkan konsumsi pakan dan memperbaiki performa ayam pedaging fase finisher. Salah satu bentuk pakan yang biasa diberikan adalah bentuk pellet.

Pellet merupakan salah satu bentuk pakan yang dapat digunakan sebagai pakan ayam pedaging. Pellet merupakan pakan yang dipadatkan, dikompakkan melalui proses mekanik. Pellet dapat dicetak dalam bentuk gumpalan dan silinder kecil yang berbeda diameter, panjang dan tingkat kekuatannya (Ensminger, et al., 1990). Kendala penggunaan pakan bentuk pellet adalah mudah mengalami kerusakan pada saat pengangkutan dan penyimpanan karena strukturnya yang kurang kuat dan mudah hancur. Cara untuk mengatasi masalah ini adalah dengan menggunakan bahan perekat saat pembuatan pakan sehingga pellet yang dihasilkan akan lebih baik. Perekat merupakan suatu bahan yang berfungsi untuk mengikat komponen dalam pakan bentuk pellet sehingga strukturnya tetap kompak dan kuat. Bahan perekat alami telah banyak digunakan sebagai bahan perekat untuk berbagai pakan, antara lain tepung tapioka, tepung gaplek, molases, serta rumput laut (Sari, et al., 2016).

Bahan perekat tepung tapioka dan molases mengandung pati yang merupakan bahan pembentuk zat perekat. Pati akan membentuk gel yang sangat membantu dalam proses pembuatan pakan agar menjadi lebih padat, keras serta tidak mudah pecah (Rasidi, 1997). Murtidjo (1987) menyatakan bahwa dalam penyusun pakan ternak bentuk pellet bisa mempergunakan campuran tepung tapioka sekitar $2 \%$ sampai 5\%, terutama untuk bahan baku yang bisa berfungsi sebagai perekat yang efektif.

Perekat berfungsi mengikat komponen-komponen pakan dalam bentuk pellet sehingga strukturnya tetap kompak. Perekat yang biasa digunakan pabrik-pabrik pakan ternak adalah perekat sintetis seperti bentonit dan lignosulfonat (Retnani, et al., 2010). Penggunaan bahan perekat bentonit dan lignosulfonat dengan beberapa proses pengolahan yaitu dengan penyemprotan $5 \%$ air, penyemprotan $5 \%$ air panas dan pemanasan 45 menit. Diperoleh hasil bahwa penambahan bahan perekat 2,5\% bentonit dan 1,25\% lignosulfonat meningkatkan sifat fisik ransum ayam broiler starter bentuk pelet dan pengolahan dengan pemanasan selama 45 menit meningkatkan ketahanan benturan pellet (Harmiyanti, 2002). Hasil penelitian Retnani, et al (2011) penggunaan bahan perekat bentonit $2 \%$ menghasilkan persentase durability pellet sebesar $95 \%$. Perekat sintetis relatif mahal sehingga perlu adanya alternatif bahan perekat dari bahan lokal yang murah dan alami seperti tepung tapioka dan molases. Penelitian ini bertujuan untuk mengetahui pengaruh penggunaan bahan perekat molases, tepung tapioka serta bentonit terhadap kerapatan tumpukan (bulk density), ketahanan pellet (pellet durability index) dan kekerasan pellet (hardness of pellet) pakan pellet pakan ayam pedaging fase finisher. 


\section{Metode Penelitian}

Penelitian ini dilaksanakan pada bulan Juni sampai Juli 2020 di Laboratorium Teknologi dan Industri Pakan Fakultas Peternakan, Universitas Hasanuddin, Makassar dan PT. Japfa Comfeed Indonesia, Tbk. Makassar. Penelitian menggunakan rancangan acak lengkap (RAL) dengan empat perlakuan dan empat ulangan. Susunan perlakuan yaitu P0 : ransum ayam pedaging fase finisher tanpa menggunakan bahan perekat, P1: ransum ayam pedaging fase finisher + Molases 2\%, P2: ransum ayam pedaging fase finisher + Tepung tapioka 2\%, P3: ransum ayam pedaging fase finisher + bentonit $2 \%$. Pelaksanaan penelitian dilakukan dengan tahapan penyiapan ransum, formulasi ransum, pencampuran pakan, penambahan bahan perekat, penambahan air, proses pemelletan, pendinginan dan pengeringan, pengambilan sampel serta pengukuran parameter penelitian.

Ransum ayam pedaging fase finisher disusun berdasarkan standar kebutuhan ayam pedaging fase finisher sesuai dengan SNI 8173.3:2015. Komposisi ransum adalah konsentrat ayam pedaging fase finisher dalam bentuk mash (50\%) yang diproduksi oleh PT. Charoend Pokphand Indonesia, jagung (35\%) yang diperoleh dari CV. Barbas Agro Celebes serta dedak padi padi (25\%) yang diperoleh dari pabrik penggilingan padi di Kabupaten Sidrap. Kualitas bahan ransum yang digunakan seperti terlihat pada Tabel 1 .

Tabel 1. Kandungan nutrisi bahan penyusun ransum

\begin{tabular}{lccc}
\hline \multirow{2}{*}{$\begin{array}{c}\text { Kandungan } \\
\text { Nutrisi }\end{array}$} & $\begin{array}{c}\text { Konsentrat ayam Penyusun Ransum } \\
\text { pedaging fase } \\
\text { Finisher }\end{array}$ & Jagung & $\begin{array}{c}\text { Dedak } \\
\text { padi }\end{array}$ \\
\hline $\begin{array}{l}\text { Kadar Air (\%) } \\
\begin{array}{l}\text { Protein Kasar } \\
(\%)\end{array}\end{array}$ & 10,32 & 10,72 & 10,79 \\
Serat Kasar (\%) & 37,66 & 8,78 & 7,34 \\
$\begin{array}{l}\text { Lemak Kasar } \\
(\%)\end{array}$ & 4,04 & 3,31 & 8,23 \\
Abu (\%) & 17,42 & 5,35 & 10,6 \\
\hline
\end{tabular}

Ransum yang telah dicampur ditambahkan bahan perekat sesuai dengan perlakuan. Bahan perekat di campur secara manual, serta penambahan air dilakukan dengan cara menyemprotkan air menggunakan pressure sprayer ke dalam ransum yang telah di beri bahan perekat secara manual. Penambahan kadar air berdasarkan kondisi kadar air awal bahan hingga mencapai pada taraf 30-35\% di ukur menggunakan grain moisture tester. Proses pemelletan menggunakan mesin pellet jenis farm feed pelleter. Pellet yang diproduksi selanjutnya dilakukan pendinginan (suhu ruang) dan pengeringan dengan bantuan sinar matahari hingga kadar air pellet pada taraf kadar air 10-12\%.

Pengambilan sampel untuk pengukuran parameter menggunakan metode quartering berdasarkan SNI 13-67172002. Parameter yang diamati adalah kerapatan tumpukan (bulk density), ketahanan pellet (pellet durability index) dan kekerasan pellet (hardness of pellet). Data yang diperoleh diolah dengan analisis ragam menggunakan data analysis microsoft office excel series 365 dan dilanjutkan dengan uji beda nyata terkecil.

\section{Hasil dan Pembahasan}

Rata-rata pengaruh berbagai bahan perekat terhadap kerapatan tumpukan (bulk density), ketahanan pellet (pellet durability index) dan kekerasan pellet (hardness of pellet) pakan pellet ayam pedaging finisher dapat dilihat pada Tabel 2.

Tabel 2. Rata-rata Pengaruh Berbagai Bahan Perekat Terhadap Kualitas Fisik Pakan Pellet Ayam Pedaging Finisher

\begin{tabular}{cccc}
\hline \multirow{3}{*}{$\begin{array}{c}\text { Perlakua } \\
\mathrm{n}\end{array}$} & $\begin{array}{c}\text { Kerapatan } \\
\text { Tumpukan } \\
(\text { Bulk Density }) \\
\left(\mathrm{kg} / \mathrm{m}^{3}\right)\end{array}$ & $\begin{array}{c}\text { Pellet } \\
\text { Durability } \\
\text { Index }(\%)\end{array}$ & $\begin{array}{c}\text { Kekerasan } \\
(\text { Hardness }) \\
(\mathrm{kg})\end{array}$ \\
\hline P0 & $608,20^{\mathrm{a}} \pm 13,61$ & $95,03^{\mathrm{a}} \pm 0,0079$ & $3,2492^{\mathrm{a}} \pm 0,92$ \\
P1 & $577,65^{\mathrm{b}} \pm 6,52$ & $95,19^{\mathrm{a} \pm} 0,0027$ & $3,5660^{\mathrm{a}} \pm 0,89$ \\
P2 & $576,80^{\mathrm{b}} \pm 7,72$ & $96,26^{\mathrm{b} \pm} 0,0049$ & $3,7414^{\mathrm{a}} \pm 0,74$ \\
P3 & $573,05^{\mathrm{b}} \pm 9,22$ & $96,83^{\mathrm{b} \pm} 0,0020$ & $5,0821^{\mathrm{b}} \pm 1,35$ \\
\hline
\end{tabular}

Keterangan: Superskrip yang berbeda pada kolom yang sama menunjukkan perbedaan nyata $(\mathrm{P}<0.05)$. $\mathrm{P} 0=$ ransum ayam pedaging fase finisher tanpa menggunakan bahan perekat; $\mathrm{P} 1=$ ransum ayam pedaging fase finisher +molases $2 \%$; P2 $=$ ransum ayam pedaging fase finisher + tepung tapioka $2 \% ; \mathrm{P} 3=$ ransum ayam pedaging fase finisher + bentonit $2 \%$.

\subsection{Kerapatan tumpukan (bulk density)}

Analisis ragam menunjukkan bahwa penambahan berbagai bahan perekat berpengaruh nyata $(\mathrm{P}<0.05)$ terhadap nilai kerapatan tumpukan pakan pellet ayam pedaging fase finisher. Penambahan bahan perekat menghasilkan pellet yang kompak kerena kandungan pati pada bahan perekat menyebabkan terjadinya proses gelatinisasi yang mengikat tiap komponen pakan sehingga volume pellet yang di hasilkan semakin kecil dan volume ruang yang di tempati semakin besar. Di lain pihak, pellet tanpa penambahan bahan perekat tidak mengalami proses gelatinisasi yang maksimal sehingga memiliki volume pellet yang lebih besar dan volume ruang yang di tempati lebih kecil.

Berdasarkan uji beda nyata terkecil menunjukkan kerapatan tumpukan (bulk density) pakan pellet ayam pedaging fase finisher pada perlakuan P0 (pellet tanpa bahan perekat) berbeda nyata lebih tinggi $(\mathrm{P}<0.05)$ dibanding perlakuan P1 (pellet dengan bahan perekat molases), P2 (pellet dengan bahan perekat tepung tapioka) dan P3 (pellet dengan bahan perekat bentonit). Di lain pihak, perlakuan P1, P2 dan P3 tidak menunjukkan perbedaan kerapatan tumpukan (bulk density). Tingginya kerapatan tumpukan (bulk density) pada perlakuan tanpa bahan perekat diduga disebabkan oleh kecilnya ukuran partikel pellet dibandingkan pellet dengan penambahan bahan perekat. Hasil ini sesuai dengan pendapat Agustina (2015) bahwa ukuran partikel pellet yang semakin besar dapat menurunkan nilai kerapatan tumpukan pellet. 
Kerapatan tumpukan digunakan untuk menentukan volume ruang penyimpanan bahan dengan berat tertentu (Syarief dan Irawati, 1993). Nilai rataan kerapatan tumpukan yang semakin menurun dapat memperbesar volume ruang penyimpanan. Semakin tinggi nilai kerapatan tumpukan maka ruang penyimpanan yang dibutuhkan semakin kecil (Khalil, 1999; Syamsu, 2007).

\subsection{Ketahanan pellet (pellet durability index)}

Analisis ragam menunjukkan bahwa penambahan berbagai bahan perekat berpengaruh nyata $(\mathrm{P}<0.05)$ terhadap nilai pellet durability index pakan pellet ayam pedaging fase finisher. Pellet durability index di pengaruhi oleh keefektifan daya lengket bahan perekat. Daya lengket sangat erat hubungannya dengan proses gelatinisasi dari pati bahan perekat. Pakan pellet tanpa bahan perekat menunjukkan rataan nilai pellet durability index terendah yaitu $95,03 \%$ dan pakan pellet dengan bahan perekat bentonit dengan nilai rataan pellet durability index tertinggi yaitu $96,83 \%$.

Berdasarkan uji beda nyata terkecil pengaruh berbagai bahan perekat terhadap pellet durability index pakan pellet ayam pedaging fase finisher, bahwa P0 (pellet tanpa bahan perekat) tidak menunjukkan perbedaan dengan P1 (pellet dengan bahan perekat molases) dan P2 (pellet dengan bahan perekat tepung tapioka) tidak menunjukkan perbedaan dengan P3 ( pellet dengan bahan perekat bentonit). Di lain pihak, perlakuan $\mathrm{P} 0$ dan $\mathrm{P} 1$ berbeda nyata $(\mathrm{P}<0,05)$ dengan P2 dan P3. Rataan nilai pellet durability index sesuai dengan pendapat Dozier (2001) bahwa nilai durability untuk pellet broiler adalah minimum $80 \%$.

Kandungan pati pada bahan mempengaruhi proses pelleting, semakin banyak pati yang diubah oleh panas membantu meningkatkan proses perekatan partikel-partikel dalam pellet sehingga meningkatkan ketahanan pellet. Hal ini sesuai dengan pendapat Rasidi (1997) bahwa ketahanan pellet di pengaruhi oleh banyak pati yang diubah oleh uap panas menjadi perekat sehingga dapat membantu proses perekatan partikel-partikel dalam pellet. Pellet yang kuat, kokoh serta tidak mudah hancur membantu proses penanganan dan pengangkutan (transportasi) agar tetap utuh.

\subsection{Kekerasan pellet (hardness of pellet)}

Analisis ragam menunjukkan bahwa penambahan berbagai bahan perekat berpengaruh nyata $(\mathrm{P}<0.05)$ terhadap nilai hardness pakan pellet ayam pedaging fase finisher. Penambahan bahan perekat khususnya bentonit mengakibatkan ikatan antar partikel bahan penyusun pellet menjadi kuat sehingga bahan tidak terisi rongga udara pada proses penekanan. Pellet dengan rongga udara sedikit menghasilkan tekstur pellet yang kompak dan akan tahan terhadap proses penekanan.

Pada Tabel 4 terlihat bahwa pakan pellet dengan bahan perekat bentonit mempunyai nilai rata-rata hardness tertinggi yaitu $5,0821 \mathrm{~kg}$, nilai tersebut menunjukkan kekuatan (gaya) yang dibutuhkan untuk menekan pellet sampai pecah (Thomas dan Van Der Poel, 1996). Berdasarkan uji beda nyata terkecil berbagai bahan perekat terhadap hardness pakan pellet ayam pedaging fase finisher menyatakan bahwa P0 (pellet tanpa bahan perekat) tidak menunjukkan perbedaan dengan P1 (pellet dengan bahan perekat molases) dan P2 (Pellet dengan bahan perekat tepung tapioka) namun berbeda nyata $(\mathrm{P}<0.05)$ dengan $\mathrm{P} 3$ (Pellet dengan bahan perekat bentonit).

Nilai hardness dapat dipengaruhi oleh beberapa faktor diantaranya penggunaan sampel pellet selama pengukuran. Pengukuran hardness dapat dipengaruhi oleh beberapa faktor diantaranya variasi panjang pelet yang berbeda, perbedaan tekanan yang diterima serta adanya keretakan pada pellet (Rakhmawati, dkk., 2017). Nilai hardness mempunyai variasi yang disebabkan oleh beberapa hal, yaitu variasi panjang pellet, pellet lebih panjang biasanya memerlukan pemecahan yang lebih besar dibanding pellet yang pendek, adanya keretakan pada pellet serta pada beberapa kasus disebabkan karena kompresi yang diterima oleh bahan selama proses pembuatan pellet berbeda-beda (Tabil et al., 1997). Kualitas pellet minimum yang direkomendasikan untuk pabrik pakan 3,92 kg (Kaliyan dan Morey, 2009).

\section{Kesimpulan}

Berdasarkan hasil penelitian dapat disimpulkan bahwa tidak ada perbedaan kerapatan tumpukan (bulk density) pakan pellet ayam pedaging fase finisher dari berbagai penambahan bahan perekat. Namun, terdapat perbedaaan kerapatan tumpukan dengan pakan pellet ayam pedaging fase finisher tanpa penambahan bahan perekat. Tingginya kerapatan tumpukan pellet pada perlakuan tanpa bahan perekat diduga disebabkan oleh kecilnya ukuran partikel pellet dibandingkan pellet dengan penambahan bahan perekat. Efektivitas penggunaan perekat tepung tapioka dan bentonit menunjukkan pellet durability index yang lebih tinggi di banding penambahan bahan perekat molases. Nilai kekerasan (hardness) pellet dengan penambahan bahan perekat bentonit lebih tinggi di banding bahan perekat tepung tapioka dan molases.

\section{Ucapan Terima Kasih}

Terima kasih kepada Dekan dan Ketua Program Studi Peternakan Fakultas Peternakan Universitas Hasanuddin atas dukungan dan bantuannya sehingga penelitian ini dapat diselesaikan yang merupakan penelitian tugas akhir (skripsi).

\section{Daftar Pustaka}

Agustina, Y. 2005. Kualitas fisik pellet ransum broiler mengandung bahan dengan ukuran partikel yang berbeda pada proses produksi berkesinambungan. Skripsi. Fakultas Peternakan. Institut Pertanian Bogor. Bogor.

Dozier, W. A. 2001. Pellet quality for more economical poultry meat. Journal Feed International. 52(2): 40-42.

Ensminger M. E., Oldfield J. E., and W. W. Heinnmann. 1990. Feed and Nutrition. 2nd Edition. California (US): The Ensminger Publishing Company.

Kaliyan, N., and R. V. Morey 2009. Factors affecting strength and durability of densified biomass products. Journal Biomass and Bioenergy. 33(3): 337-359.

Khalil. 1999. Pengaruh kandungan air dan ukuran partikel terhadap sifat fisik pakan lokal: kerapatan tumpukan, kerapatan pemadatan tumpukan, dan berat jenis. Media Peternakan. 22(1): 1-11. 
Murtidjo, B. A. 1987. Pedoman Meramu Pakan Unggas. Yogyakarta: Kanisius.

Rakhmawati, Y. E., Sulistiyanto B dan Sumarsih. 2017. Mutu fisik organoleptik pelet limbah penetasan dengan penambahan bentonit dan lama penyimpanan yang berbeda. Prosiding Seminar Nasional Teknologi Peternakan dan Veteriner. Hal: 656-663.

Rasidi. 1997. 302 Formulasi Pakan Lokal Alternatif Untuk Unggas. Jakarta: Penebar Swadaya.

Retnani, Y., N. Hasanah, Rahmayeni dan L. Herawati. 2010. Uji sifat fisik ransum ayam broiler bentuk pellet yang ditambahkan perekat onggok melalui proses penyemprotan air. Agripet. 11(1): 13-18.

Sari, Y. I., Limin S, dan Suparmono. 2016. Kajian pengaruh penambahan tepung tapioka sebagai binder dalam pakan buatan terhadap pertumbuhan ikan nila gift (Oreochromis, Sp). e-JRTBP. 5.

Standar Nasional Indonesia. 2002. Tata cara penyiapan benda uji dari contoh agregat. Badan Standardisasi Nasional. (SNI 13-6717-2002).

Standar Nasional Indonesia. 2015. Pakan ayam ras pedaging (broiler) Bagian 3: masa akhir (finisher). Badan Standardisasi Nasional. (SNI 8173.3:2015).

Syamsu, J. A. 2007. karakteristik fisik pakan itik bentuk pellet yang diberi bahan perekat berbeda dan lama penyimpanan yang berbeda. Jurnal Ilmu Ternak, 7 (2) : 128-134

Syarief, R dan Irawati, A. 1993. Pengetahuan Bahan Untuk Industri Pertanian. PT. Gramedia Pustaka Utama, Jakarta.

Tabil, L. G., S. Sokhansanj and R. T. Tyler. 1997. Performance different binders during alfalfa pelleting. Canadian Agricultural Engineering. 39(1):17-23.

Thomas, M, and A. F. B Van Der Poel. 1996. Physical quality of pelleted animal feed. 1. Criteria for pellet quality. Animal Feed Sci. Tech. 61: 89-112. 